Environment, Biodiversity \& Soil Security
(EBSS)

\title{
Antagonistic Activity of Some Bioagents against Root Rot Diseases of Pepper (Capsicum annum L.)
}

Nahla I. H. El-Feky ${ }^{1,2}$, T. A. Essa ${ }^{2}$, Abdelnaser A. Elzaawely ${ }^{1 *}$ and Hassan M. El-Zahaby ${ }^{1}$ ${ }^{1}$ Department of Agricultural Botany, Faculty of Agriculture, Tanta University, Tanta 31527, Egypt

${ }^{2}$ Department of Vegetable Diseases Research, Plant Pathology Research Inst., Agricultural Research Centre, Giza, Egypt

$\mathbf{E}$ IGHT isolates of bioagents (fungal and bacterial), obtained from the rhizosphere of healthy pepper plants collected from various pepper-growing sites in Kafr El-Sheikh governorate, were tested against pepper root-rot pathogens including Pythium aphanidermatum, Fusarium solani, F. oxysporum, F. moniliformis and Macrophomina phaseolina. In in vitro study, the fungal bioagents (Trichoderma viride (TV1 and TV2) and T. harzianum (TH1 and TH2) exhibited the maximum antifungal activity against the five phytopathogens compared to the bacterial bioagents (Pseudomonas fluorescens (P1 and P2) and Bacillus subtilis (B1 and B2). In pots experiment, TV1 and $\mathrm{P} 2$ bioagents caused the least disease severity among all treatments. All bioagents were effective with different degrees specially Trichoderma spp. to promote the growth parameters of pepper plants and manage root rot disease that caused by different pathogens. Furthermore, they had equal efficacy with fungicide treatment under in vitro and in pots experiment. Thus, application of biological methods in plant disease control is an effective alternative technique and could have a potential biofertilizer effect, since they stimulated the growth of pepper plants.

Keywords: Pepper, Biological control, Root rot, Bioagents

\section{Introduction}

Sweet pepper (Capsicum annuum L.) belongs to the family Solanaceae, which is an important group of vegetables extensively cultivated in Egypt and all over the world. The total cultivated area of pepper in Egypt reached 41,047 ha and producing 623,221 tons annually (FAO, 2017). Pepper plants are liable to be attacked by several soil-borne pathogenic fungi, which are responsible for a considerable plant mortality and consequently high losses in the yield and quality in many countries of the world (Van Bruggen and Semenov 2000). Fusarium solani, F. oxysporum, Pythium aphanidermatum and Macrophomina phaseolina cause root rot diseases in sweet pepper plants (Kelley et al., 2009; Wilson et al., 2010 and Mmbaga \& Gurung, 2018).

Biological control is a viable strategy for disease management and sustainable pepper production
(Velivelli et al., 2014). Bioagents antagonize pathogens directly by hyperparasitism, production of antibiotics and lytic enzymes, and indirectly by competing for space and nutrients, inducing systemic resistance, and promoting plant growth (Pal and Gardener, 2006; Velivelli et al., 2014). Bioagents secrete enzymes such as chitin, proteins, cellulose, and hemicellulose that are able to hydrolyze mycelium and spores of fungal pathogen as a direct suppression of plant pathogens (Solanki et al., 2011).

Trichoderma spp. is one of the important bioagents used for management of different diseases in several crop plants (Kubicek et al., 2001; Hussain et al., 2017; Omara et al., 2017). Genus Trichoderma as an active soil inhabitant and root system colonizers possibly as plant symbionts as well as a parasitic to some pathogenic fungi were described by Harman et al. (2004). T. viride was reported to have the ability

${ }^{*}$ Corresponding author: Email: elzaawely@agr.tanta.edu.eg

Received 26/11/2019; Accepted 5/1/2020

DOI: $10.21608 /$ jenvbs.2020.20144.1075

C2019 National Information and Documentation Center (NIDOC) 
to inhibit soil borne pathogenic fungi in vitro. The average of inhibitory coefficient against $F$. oxysporum, F. solani and R. solani was between 70 to $80 \%$ and was attributed to either toxin production or mycoparasitism (Howell, 2003).

Pseudomonas fluorescens and Bacillus subtilis as bioagents were reported to suppress certain fungi causing root rot diseases in sweet pepper plants by producing a variety of microbial metabolites like siderophores and production of extracellular cell wall degrading enzymes, as chitinase that can lyse pathogen cell walls or plant growth regulators as IAA (Yu et al., 2011). The cell wall degrading enzymes from $P$. fluorescens has a great potential in agriculture as active components in new fungicidal formulation as found by El-Gamal et al. (2016).

The main objective of this study was to evaluate the efficacy of Trichoderma harzianum, T. viride, Pseudomonas flouresence and Bacillus subtillus in controlling pepper root rot disease in vitro and under greenhouse conditions compared with an effective fungicide.

\section{Materials and Methods}

Isolation, purification and identification of pathogenic fungi

Pepper plants showing root rot symptoms were collected from Kafr El-Sheikh governorate during all cultivation seasons of pepper plants in 2016/2017. Diseased roots were washed with tap water, cut into small pieces and surface sterilized by $0.5 \%$ sodium hypochlorite solution for three minutes and then, washed three times with sterilized distilled water. Samples were dried between two layers of sterilized filter papers to remove the excess water and placed on potato dextrose agar (PDA) medium in Petri dishes. Inoculated dishes were incubated at $18-20{ }^{\circ} \mathrm{C}$ for $4-5$ days, and the developed fungal cultures were purified by using hyphal tip isolation techniques (Brown, 1924). They were identified based on the morphological and microscopic characteristics. Identification was confirmed in the Mycological Research and Disease Survey Department, Plant Pathology Research Institute (PPRI), ARC, Giza, Egypt. The pathogenic isolates were maintained on PDA at $5 \pm 1{ }^{\circ} \mathrm{C}$.

\section{Pathogenicity test}

Pathogenicity test was conducted in October 2017/2018. The identified isolates (P. aphanidermatum, $F$. solani, F. oxysporum, F. moniliformis and $M$. phaseolina) were grown on barley-sandy medium (140 $\mathrm{g}$ barley grains, $60 \mathrm{~g}$ sand and $60 \mathrm{ml}$ water) for two weeks (Abdel-Monaim and Ismail, 2010) at $25 \pm 1{ }^{\circ} \mathrm{C}$ to test their pathogenicity. Plastic pots $(30 \mathrm{~cm}$ in diameter) containing $5 \mathrm{~kg} /$ pot sterilized sandy-clay $(1: 1 \mathrm{w} / \mathrm{w})$ Env. Biodiv. Soil Security (2019) were infested with prepared inoculum at $5.0 \%$, for ten days before transplanting. Healthy seedlings (30 days old) of pepper cv. Top star were transplanted at the rate of 5 seedlings/pot. Five pots were used for each fungus. Check treatment (control) was used. The pots were kept under careful observation under greenhouse condition of the Plant Pathology Dept., Sakha station, Kafr ElSheikh governorate, Egypt.

\section{Disease assessment}

Disease severity index and disease incidence were determined on the foliar part and vascular tissue discoloration after 45 days from transplanting. Pepper plants were removed from the soil, washed thoroughly to remove soil debris, and root rot disease severity was scored based on the modified scale of (Hwang and Chang, 1989) as follows:

$0=$ neither root discoloration nor leaf yellowing, $1=$ $1-25 \%$ root discoloration or one leaf yellowed, $2=26-$ $50 \%$ root discoloration or more than one leaf yellowed, $3=51-75 \%$ root discoloration or vascular discoloration plus one leaf wilted, $4=$ up to $76 \%$ root discoloration or more than one leaf wilted or completely dead plants. For each replicate, a disease severity index (DSI) similar to the one described by Liu et al. (1995) was calculated as follows:

$\mathrm{DSI}=\Sigma \mathrm{d} /(\mathrm{d} \max \times \mathrm{n}) \times 100$

Whereas $d$ is the disease rating of each plant, $d$ max is the maximum disease rating and $\mathrm{n}$ is the total number of plants examined in each replicate.

Additionally, the disease incidence was estimated using the following equation:

$\%$ Disease incidence $=\frac{\text { Number of infected plants }}{\text { Total number of plants }} 100 \times$

Isolation and identification of antagonistic rhizosphere microorganisms from healthy roots of pepper plants

The serial dilution method was used for isolation of antagonistic rhizosphere microorganisms of healthy pepper roots collected from Kafr El-Sheikh governorates (Iqbal and Ashraf, 2017). After an incubation period, fungal or bacterial colonies were purified and identified according to their cultural, morphological and physiological characters. Bacterial isolates were identified based on Bergey's Manual of Systematic Bacteriology (1984) using the methods recommended by Parry et al. (1983). On the other hand, fungal isolates were subjected to identification tests according to the methods stated by Domsch et al. (1980). Identification was confirmed through both of the Mycological Research and Disease Survey Department and Bacterial Disease Department, Plant Pathology Research Institute, ARC, Giza, Egypt as shown in Table 1. 


\section{TABLE 1. Fungal and bacterial isolates used as bioagents}

\begin{tabular}{ll}
\hline Name of isolate & Code \\
\hline Trichoderma harzianum 1 & TH1 \\
Trichoderma harzianum 2 & TH2 \\
Trichoderma viride 1 & TV1 \\
Trichoderma viride 2 & TV2 \\
Pseudomonas fluorescens 1 & $\mathrm{P} 1$ \\
Pseudomonas fluorescens 2 & $\mathrm{P} 2$ \\
Bacillus subtilis 1 & $\mathrm{~B} 1$ \\
Bacillus subtilis 2 & $\mathrm{~B} 2$
\end{tabular}

Bioagents culture and inoculum preparation

T. harzianum and T. viride strains were grown on PDA and incubated at $25 \pm 2^{\circ} \mathrm{C}$ for 7 days and maintained refrigerated at $4^{\circ} \mathrm{C}$ until use. B. subtilis strains were maintained on nutrient medium (Difco, 1985) for $48 \mathrm{~h}$ at $28 \pm 2^{\circ} \mathrm{C}$ and maintained refrigerated at $4^{\circ} \mathrm{C}$ until use. Whereas, $P$. fluorescens was cultured and maintained on King's medium (King et al., 1954) at $28 \pm 2^{\circ} \mathrm{C}$ for 5 days and maintained refrigerated at $4^{\circ} \mathrm{C}$ until use.

Antifungal activity of isolated bioagents in vitro

An in vitro preliminary antifungal assay was performed using eight bioagents and fungicide Hatric 6\% (RS)- 1 -p-chlorophenyl 4,4-dimethyl -3(1 H- 1,2,4-triazol - 1 -methyl)pentan-3-ol) used as a recommended dose at the rate of $(1 \mathrm{~cm} / \mathrm{L}$ water $)$ as a positive control on PDA (for fungi) or nutrient agar (NA) for bacteria using the linear growth method against of $P$. aphanidermatum, F. solani, F. oxysporum, F. moniliformis and M. phaseolina.

Assays were performed in Petri dishes $(90 \mathrm{~mm})$ containing $20 \mathrm{ml}$ of PDA or NA medium that were inoculated with a $5 \mathrm{~mm}$ disc in diameter of pathogenic isolates at $1 \mathrm{~cm}$ distance from the edge of Petri dishes, whereas the opposite side ( $1 \mathrm{~cm}$ distance from the edge) was inoculated with either discs of $T$. harzianum or $T$. viride isolates or with streaking the $B$. subtilis or $P$. fluorescens strains.

Meanwhile, fungicide treatment was added as recommended dose $1 \mathrm{~cm} / \mathrm{L}$ to the sterilized PDA medium before solidifying and gently rotating and disbanding into sterilized Petri plates and inoculated at the middle with equal disks of pathogenic isolates then incubated at $25 \pm 2^{\circ} \mathrm{C}$. The antifungal activity of bioagents and fungicide were evaluated as a percentage of inhibition in the mycelial growth of as described by Ferreira et al. (1991) using the following formula:

Where:

$\% \mathbf{I}=$ Percentage of growth inhibition.
$\mathbf{A}=$ the distance of mycelial growth of the pathogenic fungus (control).

$\mathrm{B}=$ the distance of mycelial growth of the pathogenic fungus in the treatment.

Greenhouse experiments

Inoculum of pathogenic isolates and soil treatment

Greenhouse experiment was conducted in February $2018 / 2019$ to evaluate the effect of selected bioagents compared with the fungicide on the incidence of root rot disease on pepper plants. The five isolates of root rot fungi mentioned above were grown on barleysandy medium on glass bottles of $500 \mathrm{ml}$ capacity for two weeks at $25 \pm 1{ }^{\circ} \mathrm{C}$. Plastic pots $(30 \mathrm{~cm}$ in diameter) containing sterilized sandy-clay soil $(1: 1 \mathrm{w} / \mathrm{w})$ were infested individually with inoculums of each fungus. Fungal inoculum was mixed with the sterilized soil surface of each pot at rate of $5 \%(\mathrm{w} / \mathrm{w})$ potential inoculum. The soil was then moistened with water for ten days before transplanting. Check treatment (control) was prepared without the addition of the tested fungi.

Preparation of bioagents inoculum

Depending on laboratory experiments, the most effective bioagents were selected for further study. Inoculum of the selected bioagents (TV1, TH2, B1 and P2 isolates) in comparison with Hatric $6 \%$ fungicide for controlling pepper root rot disease were tested under greenhouse conditions. The experiment was carried out in randomized complete block design (RCBD) with five replicates for each particular treatment.

TV1 and TH2 strains were grown on Potato dextrose broth medium and incubated at $28 \pm 2{ }^{\circ} \mathrm{C}$ for ten days. Spore suspensions of both strains were counted and adjusted at $\left(1 \times 10^{6}\right.$ spore $\left./ \mathrm{ml}\right)$ each using a haemocytometer slide. Furthermore, B1 and P2 isolates were separately grown on nutrient broth medium and incubated at $28 \pm 2^{\circ} \mathrm{C}$ for $4-5$ days in $250 \mathrm{ml}$ flasks. The density of bacterial cell culture was adjusted at $\left(1 \times 10^{8} \mathrm{cfu} / \mathrm{ml}\right)$ using a haemocytometer slide (Janisiewicz and Marchi, 1992). 


\section{Plant materials}

Pepper cv. Top star seeds were obtained from the Department of Horticulture Research Institute, Giza, Egypt. The seeds were grown in the seed beds as nurseries for 4 weeks. In the greenhouse, seedlings roots (30-days old) were surface sterilized by immersing in $0.05 \%$ household bleach (Clorox $3.8 \% \mathrm{NaCl}$ ) for $3 \mathrm{~min}$ and then washed three times with sterilized water just before treating.

\section{Treatments}

The bioagents and the fungicide Hatric 6\% were applied by dipping pepper seedling (30 days old) in previous prepared treatments as mentioned before for 30 minutes in fungicide and 2 hours in suspensions of bioagents then seedlings were dried on open air before transplanting in each treatment individually. Then, soil was drenched after 7 days of transplanting with the same previous treatments at the same concentrations with $10 \mathrm{ml}$ of different treatments to each seedling in the pots. Untreated seedling was dipped in sterilized water for 30 minutes and air dried before transplanting as uninfected control. On the other hand, there was just infected control as appositive control according to each treatment individually for each pathogen separately.

Three seedlings were transplanted in each pot and 5 pots as replicates for each treatment. The pots were kept in the greenhouse $\left(25 \pm 3^{\circ} \mathrm{C}\right)$ and received the recommended dose of N, P and $\mathrm{K}$ fertilizers. Irrigation was carried out regularly and the cultivation period was extended up to 45 days after transplanting.

The pots were kept under careful observation under greenhouse condition of the Plant Pathology Dept., Sakha Station, Kafr El-Sheikh Governorate, Egypt. One week after sowing, disease severity was examined then recorded at 15, 30 and 45 days, respectively.

\section{Effect of treatments on growth parameters of pepper} plants

Growth parameters of pepper plants including shoot and root length $(\mathrm{cm})$ and dry weight $(\mathrm{g})$ were recorded in different treatments and control after 45 days of transplanting. The roots and shoots of the plant were separated and air dried before dried at $70^{\circ} \mathrm{C}$ for $48 \mathrm{~h}$ in oven till weight stability before getting the dry weight. The experiment was repeated with five replicates of each treatment.

\section{Statistical analysis}

Data were analyzed through one way analysis of variance (ANOVA) with the least significant difference (LSD) at the 0.05 probability level and Duncan's Multiple range test using CoStat Version 6.4 (CoHort Software, Monterey, CA).

\section{Results and Discussion}

Response of pepper plants to infection by some root-rot pathogens under greenhouse conditions (pathogenicity test)

In the present study, all isolates exhibited significant differences for the tested cultivar Top Star. Furthermore, observation of the symptoms showed significant differences between the isolated fungi for their pathogenicity to pepper plants.

Results in Table 2 shows that the most virulence isolates are $P$. aphanidermatum and $F$. solani that caused the highest disease severity $(97.33 \%$ and $95.00 \%$, respectively) and the highest disease incidence (72\% and $60 \%$, respectively). On the other hand, the lowest disease severity was achieved with $F$. moniliformis and M. phaseolina ( $80.42 \%$ and $80.63 \%$, respectively) and they also have the lowest disease incidence (44\% and $52 \%$, respectively). These results are in accordance with those reported by many researchers (Jayaraj et al., 2005; Jeyaseelan et al., 2012; Kipngeno et al., 2015; Elshahawy et al., 2018).

In vitro antagonistic effect of bioagents against root-rot pathogens

Different bioagents exhibited different levels of bioactivity against different root-rot pathogens as presented in Table 3. Results revealed that all fungal bioagents as well as the fungicide Hatric showed a degree of inhibition against the mycelial growth patterns of all root-rot pathogens. Contrarily, all bacterial bioagents showed antifungal activity against all tested pathogens except for $P$. aphanidermatum. In addition, $P$. fluorescens isolate $1(\mathrm{P} 1)$ had no effect on M. phaseolina.

In general, it is obvious that $\mathrm{TH} 2$ reduced the mycelial growth of the five pathogenic fungi at the range of 62.22 to $78.09 \%$, while the range of the inhibition of the mycelial growth of the same pathogens by TV1 was from 68.89 to $87.53 \%$. Results also indicated that B1 isolate reduced the mycelial growth of the four pathogenic fungi by 29.87 to $44.07 \%$, while P2 isolate reduced the mycelia growth by 33.20 to $43.67 \%$ (Table 3 and Fig. 1-5).

It is clear that the fungal bioagents significantly reduced the mycelial growth of the tested pathogenic fungi higher than the bacterial agents did. Our results are in an agreement with those recorded by Karima and Nadia (2012), who reported that Trichodermia spp. had an antagonistic ability and decreased the mycelial growth of $R$. solani but also have antifungal effect against Botrytis cinerea, Fusarium oxysporium, Macrophomina phaseolina and R. solani (Talla et al., 2015). Additionally, B. subtilis and T. harzianum were 
TABLE 2. Response of pepper plants to infection by some root-rot pathogens under greenhouse conditions

\begin{tabular}{lccc}
\hline \multirow{2}{*}{ Pathogens } & \%Disease incidence (DI\%) & \multicolumn{2}{c}{$\%$ Disease severity (DS\%) } \\
\cline { 3 - 4 } & & Foliar part & Vascular tissue \\
\hline Pythium aphanidermatum & 72 & $80.51 \mathrm{a}$ & $97.33 \mathrm{a}$ \\
Fusarium solani & 60 & $75.60 \mathrm{~b}$ & $95.00 \mathrm{a}$ \\
Fusarium oxysporum & 52 & $70.10 \mathrm{c}$ & $87.50 \mathrm{~b}$ \\
Fusarium moniliformis & 44 & $60.50 \mathrm{~d}$ & $80.42 \mathrm{c}$ \\
Macrophomina phaseolina & 52 & $60.81 \mathrm{~d}$ & $80.63 \mathrm{c}$ \\
Control & 0 & $0.00 \mathrm{e}$ & $0.00 \mathrm{~d}$ \\
L.S.D. at $\mathbf{0 . 0 5}$ & - & 4.05 & 4.43 \\
\hline - Mean values in each column followed by the same letter are not significantly different (P $\leq 0.05)$.
\end{tabular}

TABLE 3. In vitro antagonistic effect (\%inhibition) of bioagents against root-rot pathogens

\begin{tabular}{|c|c|c|c|c|c|}
\hline \multirow[b]{2}{*}{ Treatment } & \multicolumn{5}{|c|}{ Pathogens } \\
\hline & $\begin{array}{c}\text { Pythium } \\
\text { aphanidermatum }\end{array}$ & $\begin{array}{l}\text { Fusarium } \\
\text { solani }\end{array}$ & $\begin{array}{c}\text { Fusarium } \\
\text { oxysporum }\end{array}$ & $\begin{array}{c}\text { Fusarium } \\
\text { moniliformis }\end{array}$ & $\begin{array}{c}\text { Macrophomina } \\
\text { phaseolina }\end{array}$ \\
\hline $\begin{array}{l}T . \quad \text { harzianum } \\
\text { (TH1) }\end{array}$ & $59.30 \mathrm{e}$ & $70.33 \mathrm{c}$ & $81.48 \mathrm{a}$ & $61.83 \mathrm{c}$ & $62.22 \mathrm{c}$ \\
\hline $\begin{array}{l}\text { T. harzianum } \\
\text { (TH2) }\end{array}$ & $78.09 \mathrm{c}$ & $68.00 \mathrm{c}$ & $69.26 \mathrm{c}$ & $75.92 \mathrm{a}$ & $62.22 \mathrm{c}$ \\
\hline T. viride (TV1) & $87.53 b$ & $80.80 \mathrm{a}$ & $75.93 b$ & $68.89 \mathrm{~b}$ & $76.29 b$ \\
\hline T. viride (TV2) & $65.15 \mathrm{c}$ & $73.38 b$ & $71.85 \mathrm{c}$ & $67.78 b$ & $59.27 \mathrm{e}$ \\
\hline P. fluorescens (P1) & $0.00 \mathrm{f}$ & $35.93 \mathrm{e}$ & $34.80 \mathrm{f}$ & $30.00 \mathrm{e}$ & $0.00 \mathrm{~g}$ \\
\hline P. fluorescens (P2) & $0.00 \mathrm{f}$ & $41.83 \mathrm{~d}$ & $43.67 \mathrm{e}$ & $42.57 \mathrm{~d}$ & $33.20 \mathrm{f}$ \\
\hline B. subtilis (B1) & $0.00 \mathrm{f}$ & $44.07 \mathrm{~d}$ & $43.70 \mathrm{e}$ & $42.56 \mathrm{~d}$ & $29.87 \mathrm{f}$ \\
\hline B. subtilis (B2) & $0.00 \mathrm{f}$ & $43.67 \mathrm{~d}$ & $43.67 \mathrm{e}$ & $38.90 \mathrm{~d}$ & $33.20 \mathrm{f}$ \\
\hline Hatric & $93.30 \mathrm{a}$ & $43.70 \mathrm{~d}$ & $62.00 \mathrm{~d}$ & $78.52 \mathrm{a}$ & $94.40 \mathrm{a}$ \\
\hline Control & $0.00 \mathrm{f}$ & $0.00 \mathrm{f}$ & $0.00 \mathrm{~g}$ & $0.00 \mathrm{f}$ & $0.00 \mathrm{~g}$ \\
\hline L.S.D. at 0.05 & 0.32 & 2.50 & 3.81 & 3.19 & 2.82 \\
\hline
\end{tabular}

- Mean values in each column followed by the same letter are not significantly different $(\mathrm{P} \leq 0.05)$.

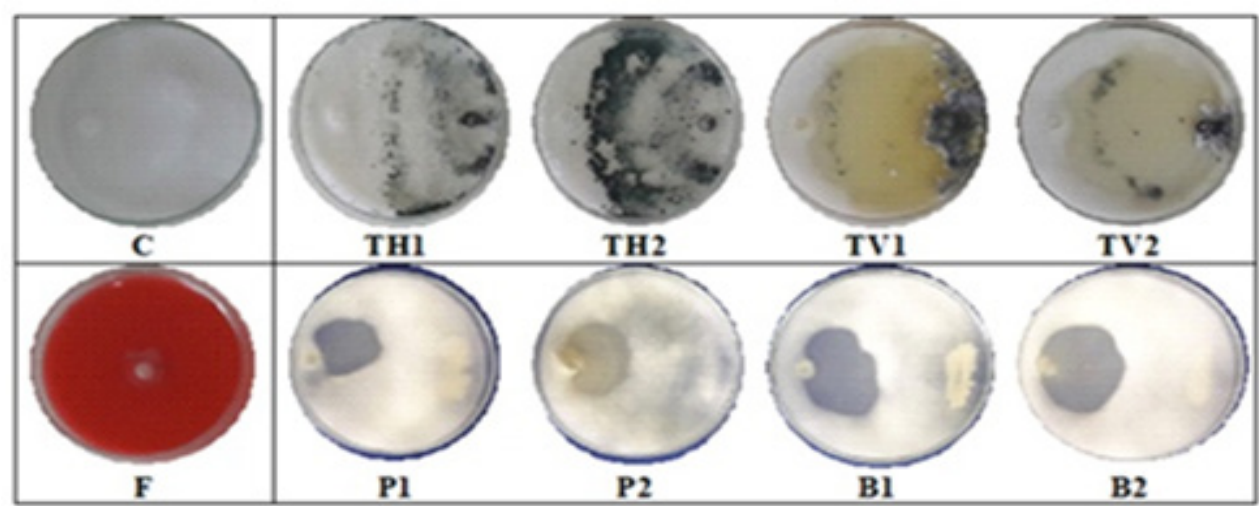

Fig. 1. Inhibition of Pythium aphanidermatum (C) growth by bioagents

- TH1, TH2: Trichoderma harzianum, TV1, TV2: T. viride, P1, P2: Pseudomonas flouresence, B1, B2: Bacillus subtilis, F: Hatric fungicid. 


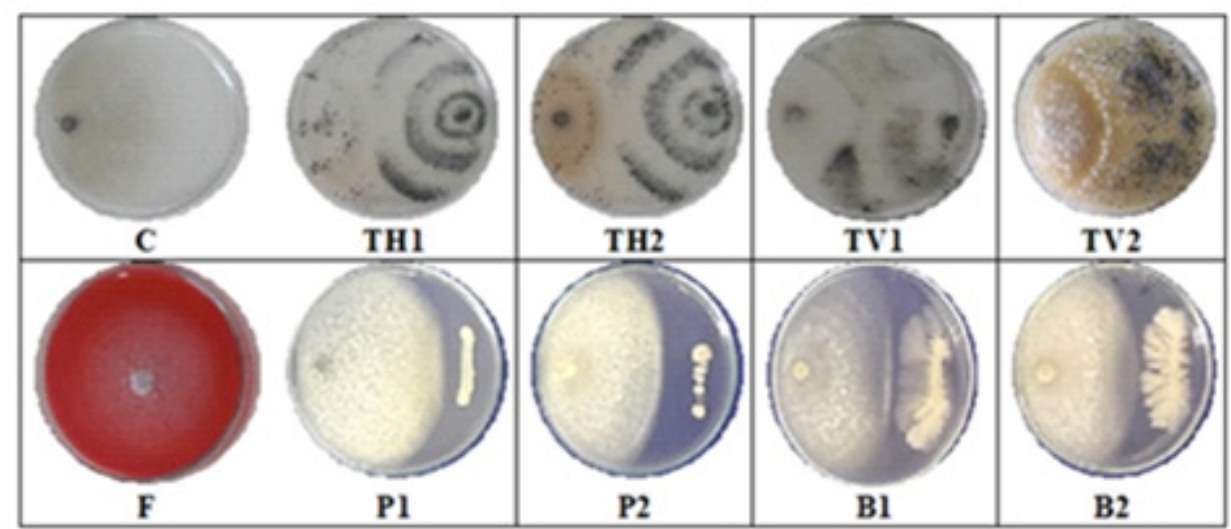

Fig. 2. Inhibition of Fusarium solani (C) growth by bioagents

- TH1, TH2: Trichoderma harzianum, TV1, TV2: T. viride, P1, P2: Pseudomonas flouresence, B1, B2: Bacillus subtilis, F: Hatric fungicid.

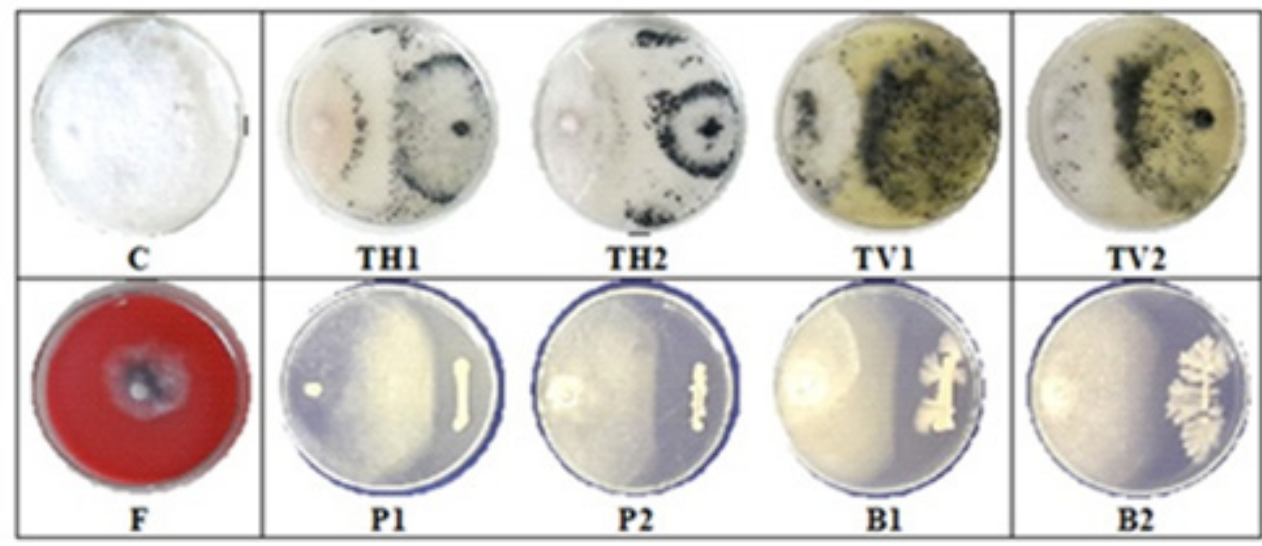

Fig. 3. Inhibition of Fusarium oxysporum (C) growth by bioagents

- TH1, TH2: Trichoderma harzianum, TV1, TV2: T. viride, P1, P2: Pseudomonas flouresence, B1, B2: Bacillus subtilis, F: Hatric fungicid.

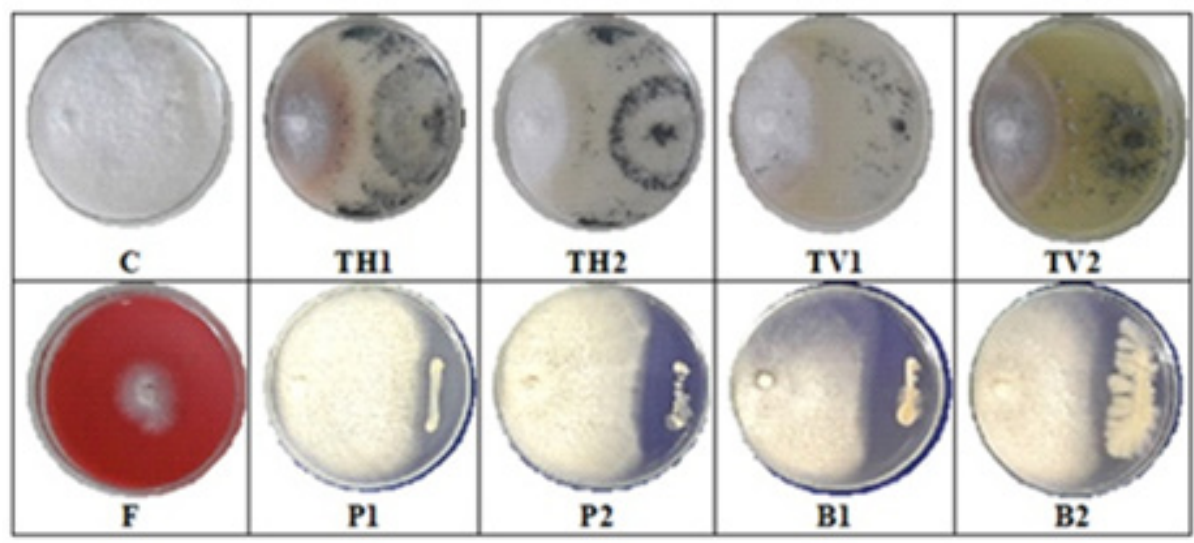

Fig. 4. Inhibition of Fusarium moniliformis (C) growth by bioagents

- TH1, TH2: Trichoderma harzianum, TV1, TV2: T. viride, P1, P2: Pseudomonas flouresence, B1, B2: Bacillus subtilis, F: Hatric fungicid. 


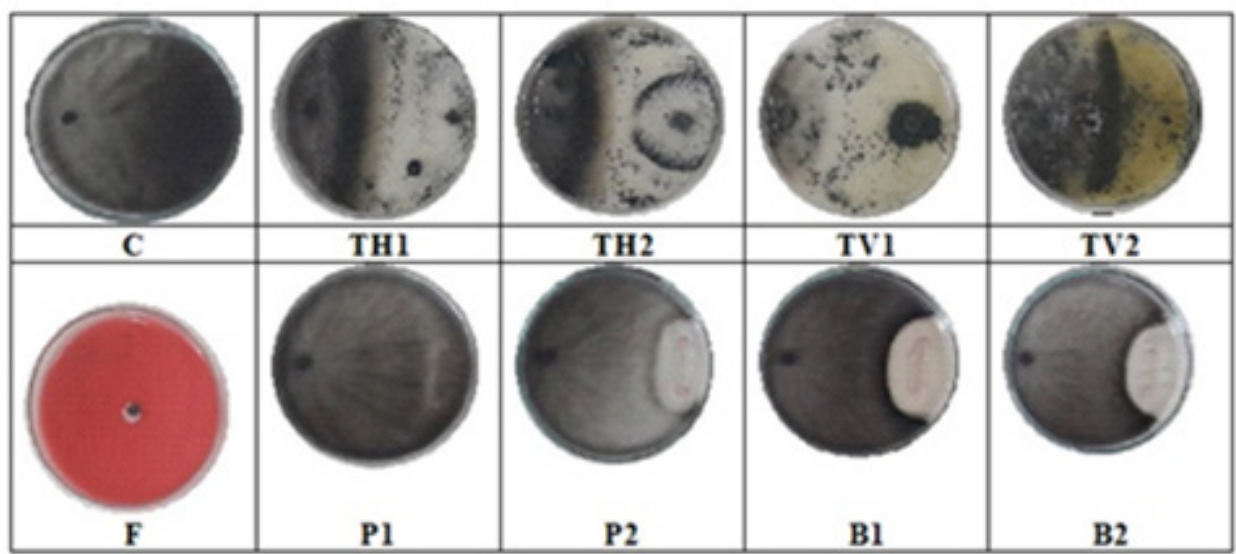

Fig. 5. Inhibition of Macrophomina phaseolina (C) growth by bioagents

- TH1, TH2: Trichoderma harzianum, TV1, TV2: T. viride, P1, P2: Pseudomonas flouresence, B1, B2: Bacillus subtilis, F: Hatric fungicid.

effective against M. phaseolina in Geranium sp. (Ghazi et al., 2018). Furthermore, it has been mentioned that the antagonistic effect of Trichoderma may be due to faster mycelia growth than pathogenic fungi (Melo and Foull, 2000; Huang et al., 2011). Meanwhile, $B$. subtilis and P. fluorescens also play an important role in controlling the soil-borne pathogens by producing the antibiotics and sidrophoroes (Roberti and Selmi, 1999).

Effect of some bioagents on pepper root-rot pathogens under greenhouse conditions

From the in vitro study, two fungal bioagents $T$. viride (TV1) and T. harzianum (TH2) as well as two bacterial isolates B. subtilis (B1) and P. fluorescens (P2) that were superior to other bioagents, were selected for continues studies under greenhouse conditions. The fungicide Hatric was used as a positive control in this experiment.

Results presented in Table 4 show that the highest antagonistic effect against $P$. aphanidermatum was obtained with the application of P2 isolate and Hatric (without significant differences between them), as they exhibited 66.3 and $66.03 \%$ efficacy, respectively. In the case of $F$. solani, the highest percent efficacy was achieved with TH2, TV1 or Hatric fungicid, which recorded $68.4,66.08$ and $68.1 \%$ efficacy, respectively. Furthermore, no significant differences were detected between TV1 and Hatric treatments towards $F$. oxysporum with 66.7 and $66.5 \%$ efficacy, respectively. For F. moniliformis, Hatric possessed the strongest effect recording $66.4 \%$ efficacy, followed by B1 and P2 with 41.0 and $40.5 \%$ efficacy, respectively. Moreover, Hatric fungicide reduced the disease severity of $M$. phaseolina with a $79.3 \%$ efficacy, followed by TV1 and P2 that recoded 67.8 and $67.5 \%$ efficacy, respectively.

Strains of Pseudomonas have shown efficacy in controlling a number of fungal diseases, including
Fusarium wilt in cotton and tomato (Gamliel and Katan, 1993) and $R$. solani root infection in tomato (Siddiqui and Shaukat, 2002).

The high effect of $T$. viride and T. harzianum could be explained due to the antibiotic substances, which are produced in sufficient concentration to affect the growth of soil fungi M. phaseolina (Sreedevi et al., 2011 and Muhanna et al., 2016). Moreover, the beneficial effect of $T$. viride and $T$. harzianum are due to direct mycoparasitism on the pathogenic fungi and to effects on plants such as enhancement plant development and inducing resistance (Harman, 2000).

Effect of bioagents on root and shoot length of pepper plants infected with root-rot pathogens

As shown in Table 5, root and shoot length of pepper plants, noted 45-days after transplanting, depended significantly on the antagonistic treatments tested. Most of the bioagents significantly promoted the length of roots and shoots of pepper plants infected with $P$. aphanidermatum, $F$. solani, $F$. oxysporum, $F$. moniliformis and $M$. phaseolina compared to inoculated or untreated control. Results indicated that $P$. aphanidermatum had the maximum root and shoot length when treated with P2 bioagent (12.5 and 32.0 $\mathrm{cm}$ ), while TH2 enhanced the root and shoot length of M. phaseolina recorded 9.9 and $19.5 \mathrm{~cm}$. Furthermore, TV1 bioagent possessed the highest root and shoot length of $F$. solani, F. oxysporum and F. moniliformis isolates, which recorded 11.87 and $26.83 \mathrm{~cm}, 14.13$ and $33.20 \mathrm{~cm}$ and 9.77 and $22.37 \mathrm{~cm}$, respectively (Table 5). It has been previously reported that Trichoderma are beneficial to several crop plants not only by promoting their growth but also by protecting them from the disease infection through triggering the systematic resistance (Shivanna et al., 1996). 
TABLE 4. Effect of some bioagents on pepper root-rot pathogens under greenhouse conditions

\begin{tabular}{|c|c|c|c|c|c|c|c|c|c|c|}
\hline \multirow[t]{2}{*}{ Treatment } & \multicolumn{2}{|c|}{$\begin{array}{c}\text { Pythium } \\
\text { aphanidermatum }\end{array}$} & \multicolumn{2}{|c|}{ Fusarium solani } & \multicolumn{2}{|c|}{$\begin{array}{l}\text { Pathogens } \\
\text { Fusarium } \\
\text { oxysporum }\end{array}$} & \multicolumn{2}{|c|}{$\begin{array}{c}\text { Fusarium } \\
\text { moniliformis }\end{array}$} & \multicolumn{2}{|c|}{$\begin{array}{c}\text { Macrophomina } \\
\text { phaseolina }\end{array}$} \\
\hline & DS\%* & $\mathbf{E} \% *$ & DS\% & E\% & DS\% & $\mathbf{E} \%$ & DS\% & E\% & DS\% & $\mathbf{E} \%$ \\
\hline $\begin{array}{l}\text { T. harzianum } \\
\text { (TH2) }\end{array}$ & $74.60 \mathrm{a}$ & 0.92 & $25.3 \mathrm{~d}$ & 68.40 & $74.50 \mathrm{a}$ & 1.80 & $75.5 b$ & 11.70 & $30.5 \mathrm{c}$ & 61.50 \\
\hline $\begin{array}{l}\text { T. viride } \\
\text { (TV1) }\end{array}$ & $32.90 \mathrm{c}$ & 56.31 & $27.3 d$ & 66.08 & $25.3 \mathrm{~d}$ & 66.70 & $75.8 \mathrm{~b}$ & 11.40 & $25.17 \mathrm{~d}$ & 67.80 \\
\hline $\begin{array}{l}\text { P. fluorescens } \\
\text { (P2) }\end{array}$ & $\begin{array}{c}25.30 \\
\mathrm{~d}\end{array}$ & 66.30 & $75.5 b$ & 6.20 & $30.43 c$ & 60.10 & $50.9 \mathrm{c}$ & 40.50 & $26.03 d$ & 67.50 \\
\hline $\begin{array}{l}\text { B. subtilis } \\
\text { (B1) }\end{array}$ & 50.80 & 32.50 & $50.6 \mathrm{c}$ & 32.50 & $50.2 b$ & 33.90 & $50.5 c$ & 41 & $50.5 \mathrm{~b}$ & 9.80 \\
\hline Hatric & $\begin{array}{c}25.55 \\
d\end{array}$ & 66.03 & $25.7 \mathrm{~d}$ & 68.10 & $25.3 \mathrm{~d}$ & 66.50 & $28.53 \mathrm{~d}$ & 66.40 & $14.8 \mathrm{e}$ & 79.30 \\
\hline $\begin{array}{l}\text { Infected } \\
\text { Control }\end{array}$ & $75.30 \mathrm{a}$ & - & $80.5 \mathrm{a}$ & - & $75.9 a$ & - & $85.6 \mathrm{a}$ & - & $71.5 \mathrm{a}$ & - \\
\hline $\begin{array}{l}\text { Untreated } \\
\text { Control }\end{array}$ & $0.00 \mathrm{e}$ & - & $0.00 \mathrm{e}$ & - & $0.00 \mathrm{e}$ & - & $0.00 \mathrm{e}$ & - & $0.00 \mathrm{f}$ & - \\
\hline L.S.D. at 0.05 & 1.92 & - & 2.60 & - & 3.32 & - & 2.00 & - & 3.09 & - \\
\hline
\end{tabular}

- Mean values in each column followed by the same letter are not significantly different $(\mathrm{P} \leq 0.05)$.

- DS\%*: Disease Severity percentage.

- E\%*: Efficacy percentage.

TABLE 5. Effect of bioagents on root and shoot length of pepper plants infected with root-rot pathogens

\begin{tabular}{|c|c|c|c|c|c|c|c|c|c|c|}
\hline \multirow{3}{*}{ Treatment } & \multicolumn{10}{|c|}{ Pathogens } \\
\hline & \multicolumn{2}{|c|}{$\begin{array}{c}\text { Pythium } \\
\text { aphanidermatum }\end{array}$} & \multicolumn{2}{|c|}{$\begin{array}{c}\text { Fusarium } \\
\text { solani }\end{array}$} & \multicolumn{2}{|c|}{$\begin{array}{c}\text { Fusarium } \\
\text { oxysporum }\end{array}$} & \multicolumn{2}{|c|}{$\begin{array}{c}\text { Fusarium } \\
\text { moniliformis }\end{array}$} & \multicolumn{2}{|c|}{$\begin{array}{c}\text { Macrophomina } \\
\text { phaseolina }\end{array}$} \\
\hline & Root & Shoot & Root & Shoot & Root & Shoot & Root & Shoot & Root & Shoot \\
\hline $\begin{array}{l}\text { T. harzianum } \\
\text { (TH2) }\end{array}$ & $9.17 \mathrm{c}$ & $24.67 b$ & $9.83 b$ & $24.83 b$ & $9.00 \mathrm{c}$ & $17.20 \mathrm{~d}$ & $6.90 \mathrm{c}$ & $15.67 \mathrm{~d}$ & $9.90 \mathrm{a}$ & $19.50 \mathrm{a}$ \\
\hline $\begin{array}{l}\text { T. viride } \\
\text { (TV1) }\end{array}$ & $8.17 d$ & $19.50 \mathrm{~d}$ & $11.87 \mathrm{a}$ & $26.83 a$ & $14.13 \mathrm{a}$ & $33.20 \mathrm{a}$ & $9.77 \mathrm{a}$ & $22.37 \mathrm{a}$ & $7.77 b$ & $15.83 d$ \\
\hline $\begin{array}{l}\text { P. fluorescens } \\
\text { (P2) }\end{array}$ & $12.5 \mathrm{a}$ & $32.00 \mathrm{a}$ & $8.17 \mathrm{c}$ & $13.67 \mathrm{e}$ & $9.03 \mathrm{c}$ & $16.23 \mathrm{e}$ & $7.97 b$ & $17.16 \mathrm{c}$ & $5.83 \mathrm{~d}$ & $11.70 \mathrm{f}$ \\
\hline $\begin{array}{l}\text { B. subtilis } \\
\text { (B1) }\end{array}$ & $11.43 b$ & $22.00 \mathrm{c}$ & $10.10 \mathrm{~b}$ & $25.16 \mathrm{~b}$ & $9.90 \mathrm{~b}$ & $24.43 b$ & $7.73 b$ & $14.90 \mathrm{e}$ & $6.97 \mathrm{c}$ & $16.77 \mathrm{c}$ \\
\hline Hatric & $8.17 d$ & $17.56 \mathrm{~d}$ & $6.30 \mathrm{~d}$ & $15.23 \mathrm{~d}$ & $5.36 \mathrm{~d}$ & $13.80 \mathrm{f}$ & $4.37 \mathrm{~d}$ & $12.63 \mathrm{f}$ & $4.40 \mathrm{e}$ & $12.60 \mathrm{e}$ \\
\hline $\begin{array}{l}\text { I n f e c t e d } \\
\text { Control }\end{array}$ & $3.07 \mathrm{~b}$ & $14.47 \mathrm{e}$ & $2.90 \mathrm{e}$ & $12.80 \mathrm{f}$ & $3.13 \mathrm{e}$ & $10.13 \mathrm{~g}$ & $4.06 \mathrm{~d}$ & $10.20 \mathrm{~g}$ & $3.67 f$ & $9.83 \mathrm{~g}$ \\
\hline $\begin{array}{l}\text { Untreated } \\
\text { Control }\end{array}$ & $9.70 \mathrm{c}$ & $17.96 \mathrm{~d}$ & $9.70 \mathrm{~b}$ & $17.96 \mathrm{c}$ & $9.70 \mathrm{~b}$ & $17.96 \mathrm{c}$ & $9.70 \mathrm{a}$ & $17.97 \mathrm{~b}$ & $9.70 \mathrm{a}$ & $17.97 \mathrm{~b}$ \\
\hline $\begin{array}{l}\text { L.S.D. at } \\
0.05\end{array}$ & 0.66 & 1.62 & 0.49 & 0.56 & 0.48 & 0.69 & 0.37 & 0.63 & 0.39 & 0.74 \\
\hline
\end{tabular}

- Mean values in each column followed by the same letter are not significantly different $(\mathrm{P} \leq 0.05)$.

Effect of bioagents on the root and shoot dry weight of pepper plants infected with root-rot pathogens

Results in Table 6 revealed that the tested bioagents significantly enhanced the roots and shoots dry weight of pepper plants infected with $P$. aphanidermatum, $F$. solani, F. oxysporum, F. moniliformis and $M$. phaseolina compared to the infected control treatment. Interestingly, the TV1 bioagent promoted the dry weight of pepper roots and shoots to the maximum extent that were infected with all five tested pathogens compared to other bioagents or the positive fungicide. The bioagents directly attack the plant pathogens by secreting lytic enzymes including chitinases, these enzymes hydrolysis the pathogen cell wall as chitin in principal and other components as glycan causing dramatic effect on pathogenic fungi (Chandanie et al., 2009; Hermosa et al., 2013). 
TABLE 6. Effect of bioagents on the root and shoot dry weight of pepper plants infected with root-rot pathogens

\begin{tabular}{|c|c|c|c|c|c|c|c|c|c|c|}
\hline \multirow{3}{*}{ Treatment } & \multicolumn{10}{|c|}{ Pathogens } \\
\hline & \multicolumn{2}{|c|}{$\begin{array}{c}\text { Pythium } \\
\text { aphanidermatum }\end{array}$} & \multicolumn{2}{|c|}{$\begin{array}{c}\text { Fusarium } \\
\text { solani }\end{array}$} & \multicolumn{2}{|c|}{$\begin{array}{c}\text { Fusarium } \\
\text { oxysporum }\end{array}$} & \multicolumn{2}{|c|}{$\begin{array}{c}\text { Fusarium } \\
\text { moniliformis }\end{array}$} & \multicolumn{2}{|c|}{$\begin{array}{c}\text { Macrophomina } \\
\text { phaseolina }\end{array}$} \\
\hline & Root & Shoot & Root & Shoot & Root & Shoot & Root & Shoot & Root & Shoot \\
\hline T. harzianum & & & & & & & & & & \\
\hline (TH2) & $1.97 \mathrm{~b}$ & $8.00 \mathrm{a}$ & $1.77 b$ & $6.40 \mathrm{~cd}$ & $1.83 \mathrm{bc}$ & $8.12 \mathrm{~b}$ & $1.67 \mathrm{~b}$ & $5.97 \mathrm{~d}$ & $2.47 b$ & $6.17 \mathrm{c}$ \\
\hline T. viride & & & & & & & & & & \\
\hline (TV1) & $2.2 \mathrm{a}$ & $7.07 \mathrm{a}$ & $2.40 \mathrm{a}$ & $9.73 a$ & $2.47 \mathrm{a}$ & $9.40 \mathrm{a}$ & $2.43 \mathrm{a}$ & $8.10 \mathrm{a}$ & $2.70 \mathrm{a}$ & $9.77 \mathrm{a}$ \\
\hline P. fluorescens & & & & & & & & & & \\
\hline (P2) & $1.62 \mathrm{~cd}$ & $5.50 \mathrm{~b}$ & $1.60 \mathrm{bc}$ & $5.83 \mathrm{~cd}$ & $1.70 \mathrm{bc}$ & $5.11 \mathrm{c}$ & $2.37 \mathrm{a}$ & $6.67 \mathrm{bc}$ & $2.00 \mathrm{c}$ & $6.07 \mathrm{c}$ \\
\hline $\begin{array}{l}\text { B. } \\
\text { (B1) }\end{array}$ & $1.7 \mathrm{c}$ & $5.50 \mathrm{~b}$ & $1.90 \mathrm{~b}$ & $7.00 \mathrm{bc}$ & $2.00 \mathrm{~b}$ & $5.83 \mathrm{c}$ & $1.83 b$ & $6.27 \mathrm{~cd}$ & $2.47 b$ & $8.67 b$ \\
\hline Hatric & $1.63 \mathrm{~cd}$ & $5.10 \mathrm{~b}$ & $1.70 \mathrm{bc}$ & $6.50 \mathrm{~cd}$ & $1.67 \mathrm{c}$ & $5.84 \mathrm{c}$ & $1.80 \mathrm{~b}$ & $7.10 \mathrm{~b}$ & $1.77 \mathrm{~d}$ & $6.23 c$ \\
\hline $\begin{array}{l}\text { I n f e c t e d } \\
\text { Control }\end{array}$ & $1.38 \mathrm{~d}$ & $3.76 \mathrm{c}$ & $1.33 \mathrm{c}$ & $4.46 \mathrm{e}$ & $1.23 \mathrm{~d}$ & $3.87 \mathrm{~d}$ & $1.40 \mathrm{c}$ & $4.00 \mathrm{e}$ & $1.43 \mathrm{e}$ & $2.77 \mathrm{~d}$ \\
\hline $\begin{array}{l}\text { Untreated } \\
\text { Control }\end{array}$ & $1.84 b c$ & $7.67 \mathrm{a}$ & $1.84 b$ & $7.67 b$ & $1.84 \mathrm{bc}$ & $7.67 \mathrm{~b}$ & $1.84 \mathrm{~b}$ & $7.67 \mathrm{a}$ & $1.84 \mathrm{~cd}$ & $7.67 b$ \\
\hline $\begin{array}{l}\text { L.S.D. at } \\
0.05\end{array}$ & 0.21 & 0.77 & 0.31 & 0.83 & 0.22 & 0.64 & 0.17 & 0.55 & 0.14 & 0.70 \\
\hline
\end{tabular}

- Mean values in each column followed by the same letter are not significantly different $(\mathrm{P} \leq .05)$.

According to the results of this study, biological control could be considered the best alternative and may be helpful, especially against soil borne pathogens. Obtained results match with those obtained by (Pandya and Saraf, 2010) who mentioned that biological control is a well-established fact where antagonistic fungi play an important part of biological control that gained wide acceptance next to Bacillus thuringiensis and $P$. fluorescens because of their broader spectrum in terms of disease control and yield.

\section{Conclusion}

Bioagents isolated from rhizospher of healthy pepper pants may be effective against the pepper root rot pathogens and could have a potential as biofertilizer effect, since they stimulated growth of pepper plants compared to control.

\section{References}

Abdel-Monaim, M. F., and Ismail, M. E. (2010) The use of antioxidants to control root rot and wilt diseases of pepper. Notulae Scientia Biologicae, 2 (2), 46-55.

Bergey, D. H., Holt, J. G., Krieg, N. R., Sneath, P. H. A., Mair, N. S., Sharpe, M. E. and Williams, S. T. (1984) Bergey's manual of systematic bacteriology. Williams and Wilkins, Baltimore, USA.

Brown, W. (1924) Two mycological methods. II. A method of isolation single strains on fungi by cutting out a hyphal tip. Annals of Botany, 38, 402404.

Chandanie, W. A., Kubota, M., and Hyakumachi, M. (2009) Interactions between the arbuscular mycorrhizal fungus Glomus mosseae and plant growth-promoting fungi and their significance for enhancing plant growth and suppressing dampingoff of cucumber (Cucumis sativus L.). Applied Soil Ecology, 41 (3), 336-341.

Difco, M. (1985) Dehydrated culture media and reagents for microbiology $10^{\text {th }}$ ed. Difco Labortories Defro it Michigan, USA, 4823, 487-623

Domsch, K.H., Gams, W. and Anderson, T.H. (1980) Compendium of Soil Fungi. Academic press, London, UK.

El-Gamal, N. G., Shehata, A. N., Hamed, E. R. and Shehata, H. S. (2016) Improvement of lytic enzymes producing Pseudomonas fluorescens and Bacillus subtilis isolates for enhancing their biocontrol potential against root rot disease in tomato plants. Research Journal of Pharmaceutical, Biological and Chemical Sciences, 7 (1), 1393-1400.

Elshahawy, I., Abouelnasr, H. M., Lashin, S. M. and Darwesh, O. M. (2018) First report of Pythium aphanidermatum infecting tomato in Egypt and its control using biogenic silver nanoparticles. Journal 
of Plant Protection Research, 58 (2), 137-151.

FAO. (2017) Food and Agriculture Organization of the United Nations, FAOSTAT AgricultureData.http:// www.fao.org/faostat/en/\#data/QChttp://faostat3. fao.org/browse/Q/QC/E (accessed November 8, 2019).

Ferreira, J. H., Mathee, F. N. and Thomas, A. C. (1991) Biological control of Eutypalota on grapevine by an antagonistic strain of Bacillus subtilis. Phytopathology, 81, 283-287.

Gamliel, A., and Katan, J. (1993) Suppression of major and minor pathogens by fluorescent Pseudomonads in solarized and nonsolarized soils. Phytopathology, 83, 68-75.

Ghazi, A. A., Attia, E. A., and Rashed, N. M. (2018) Management of charcoal rot (Macrophomina phaseolina) infection in geranium (Pelargonium graveolens L.) using biocontrol agents and essential oils. Environment, Biodiversity and Soil Security, 2, 131-142.

Harman, G. E. (2000) Myths and dogmas of biocontrol changes in perceptions derived from research on Trichoderma harzinum T-22. Plant Disease, 84 (4), 377-393.

Harman, G. E., Howell, C. R., Viterbo, A., Chet, I. and Lorito, M. (2004) Trichoderma species opportunistic, avirulent plant symbionts. Nature Reviews Microbiology, 2 (1), 43-56.

Hermosa, R., Rubio, M. B., Cardoza, R. E., Nicolás, C., Monte, E., \& Gutiérrez, S. (2013) The contribution of Trichoderma to balancing the costs of plant growth and defense. International Microbiology, 16 (2), 69-80.

Howell, C. R. (2003) Mechanisms employed by Trichoderma species in the biological control of plant diseases: the history and evolution of current concepts. Plant Disease, 87 (1), 4-10.

Huang, X., Chen, L., Ran, W., Shen, Q. and Yang, X. (2011) Trichoderma harzianum strain SQR-T37 and its bio-organic fertilizer could control Rhizoctonia solani damping-off disease in cucumber seedlings mainly by the mycoparasitism. Applied Microbiology and Biotechnology, 91 (3), 741-755.

Hussain, W. A., Elzaawely, A. A., El Sheery, N. I., Ismail, A. A. and El-Zahaby, H. M. (2017) Biological control of onion white rot disease caused by Sclerotium cepivorum. Environment, Biodiversity and Soil Security, 1, 101-107.

Env. Biodiv. Soil Security (2019)
Hwang, S. F. and Chang, K. F. (1989) Incidence and severity of root rot disease complex of field pea in northeastern Alberta in 1988. Canadian Plant Disease Survey, 69 (2), 139-141.

Iqbal, M. N. and Ashraf, A. (2017) Antagonism in Rhizobacteria: Application for Biocontrol of Soilborne Plant Pathogens. PSM Microbiology, 2 (3), 78-79

Janisiewicz, W. J. and Marchi, A. (1992) Control of storage rots on various pear cultivars with saprophytic strain of Pseudomonas syringae. Plant Disease (USA). 76 (6), 555- 560.

Jayaraj, J., Radhakrishnan, N. V., Kannan, R., Sakthivel, K., Suganya, D., Venkatesan, S., Velazhahan, R. (2005) Development of new formulations of Bacillus subtilis for management of tomato damping-off caused by Pythium aphanidermatum. Biocontrol Science and Technology, 15 (1), 55-65.

Jeyaseelan, E. C., Tharmila, S. and Niranjan, K. (2012) Antagonistic activity of Trichoderma spp. and Bacillus spp. against Pythium aphanidermatum isolated from tomato damping off. Archives of Applied Science Research, 4 (4), 1623-1627.

Karima, H. E. H. and Nadia, G. E. (2012) In vitro study on Fusarium solani and Rhizoctonia solani isolates causing the damping off and root rot diseases in tomatoes. Nature and Science, 10 (11), 16-25.

Kelley, W. T., Boyhan, G. E., Harrison, K. A., Granberry, D. M., Langston, D. B., Sparks, A. N. and Fonsah, E. G. (2009) Commercial Pepper Production Handbook. University of Georgia, Georgia, USA. pp. 56.

King, E. O., Ward, M. K. and Raney, D. E. (1954) Two simple media for the demonstration of phycocyanin and fluorescin. Journal of Laboratory and Clinical Medicine, 44, 301-307.

Kipngeno, P., Losenge, T., Maina, N., Kahangi, E. and Juma, P. (2015) Efficacy of Bacillus subtilis and Trichoderma asperellum against Pythium aphanidermatum in tomatoes. Biological Control, 90, 92-95.

Kubicek, C. P., Mach, R. L., Peterbauer, C. K. and Lorito, M. (2001) Trichoderma: from genes to biocontrol. Journal of Plant Pathology, 1, 11-23.

Liu, L., Kloepper, J. W. and Tuzun, S. (1995) Induction of systemic resistance in cucumber against Fusarium wilt by plant growth-promoting rhizobacteria. Phytopathology, 85 (6), 695-698. 
Melo, I. S. D. and Faull, J. L. (2000) Parasitism of Rhizoctonia solani by strains of Trichoderma spp. Scientia Agricola, 57 (1), 55-59.

Mmbaga, M. T. and Gurung, M. A. (2018) Screening of plant endophytes as biological control agents against root rot pathogens of pepper (Capsicum annum L.). Journal Plant Pathology and Microbiology, 9 (3), $2-8$.

Muhanna N. A., Essa, T. A., Manal, A. E. G. and Kamel, S. M. (2016) Efficacy of free and formulated arbuscular mycorrhiza, Trichoderma viride and Pseudomonas fluorescens on controlling tomato root rot diseases. Egyptian Journal of Biological Pest Control, 26 (3), 477- 486.

Omara, A. E. D., Hauka, F., Afify, A., Nour El-Din, M., \& Kassem, M. (2017) The role of some PGPR strains to biocontrol Rhizoctonia solani in soybean and enhancement the growth dynamics and seed yield. Environment, Biodiversity and Soil Security, 1, 47-59.

Pal, K. K. and Gardener, B. M. (2006) Biological Control of Plant Pathogens. The Plant Health Instructor. DOI: 10.1094/PHI-A-2006-1117-02.

Pandya, U. and Saraf, M. (2010) Application of fungi as a biocontrol agent and their biofertilizer potential in agriculture. J. Adv. Dev. Res., 1 (1), 90-99.

Parry, J.M., Turnbul,1 P.C.B. and Gibson, J.R. (1983) A Colour Atlas of Bacillus Species, Wolfe Medical Publications Ltd. 272 pp.

Roberti, R. and Selmi, C. (1999) Biological control of plant pathogens by Bacillus subtilis. Agricultural Science and Technology Information. 49 (7-8), 1521.

Shivanna, M. B., Meera, M. S., Kageyama, K. and Hyakumachi, M. (1996) Growth promotion ability of zoysiagrass rhizosphere fungi in consecutive plantings of wheat and soybean. Mycoscience, 37(2), 163-168.
Siddiqui, I. A. and Shaukat, S. S. (2002) Mixtures of plant disease suppressive bacteria enhance biological control of multiple tomato pathogens. Biology and Fertility of Soils, 36 (4), 260-268.

Solanki, M. K., Singh, N., Singh, R. K., Singh, P., Srivastava, A. K., Kumar, S. and Arora, D. K. (2011) Plant defense activation and management of tomato root rot by a chitin-fortified Trichoderma/ Hypocrea formulation. Phytoparasitica, 39 (5), 471.

Sreedevi, B., Charitha, M. D. and. Saigopal, D.V.R (2011) Isolation and screening of effective Trichoderma spp. against the root rot pathogen Macrophomina phaseolina. Journal of Agricultural Technology, 7 (3), 623-635.

Talla, S. G., Raju, A. S. R., Karri, S., and Kumar, Y. S. (2015) Production and antagonistic effect of Trichoderma spp. against pathogenic microorganisms (Botrytis cinerea, Fusarium oxysporium, Macrophomina phasealina and Rhizoctonia solani). African Journal of Biotechnology, 14 (8), 668-675.

Van Bruggen, A. H. and Semenov, A. M. (2000) In search of biological indicators for soil health and disease suppression. Applied Soil Ecology, 15 (1), 13-24.

Velivelli, S. L., De Vos, P., Kromann, P., Declerck, S. and Prestwich, B. D. (2014) Biological control agents: from field to market, problems, and challenges. Trends in Biotechnology, 32 (10), 493-496.

Wilson, K. G., Sandoz, E. K., Kitchens, J. and Roberts, M. (2010) The Valued Living Questionnaire: Defining and measuring valued action within a behavioral framework. The Psychological Record, 60 (2), 249-272.

Yu, X., Ai, C., Xin, L., and Zhou, G. (2011) The siderophore-producing bacterium, Bacillus subtilis CAS15, has a biocontrol effect on Fusarium wilt and promotes the growth of pepper. European Journal of Soil Biology, 47 (2), 138-145. 